\title{
The Use of Instructional Video Media to Increase The Motivation to Learn Mathematics in Grade II SDN 1 Bobotsari
}

\section{lin Setalasiah}

SD Negeri 1 Bobotsari

setalasiahiin@gmail.com

\section{Article History}

accepted 01/11/2020

approved 08/11/2020

published $15 / 11 / 2020$

\begin{abstract}
Media is an important component in increasing student motivation. The purpose of this study was to increase the learning motivation of students in learning mathematics using video media. This research is a classroom action research (PTK) which is conducted in two cycles, each cycle consisting of planning, implementation, observation, and reflection stages. The subjects of this study were 25 students of class II SD Negeri 1 Bobotsari, totaling 25 students. The research instrument was the observation sheet and documentation. Data analysis includes data reduction, data presentation, and drawing conclusions. The finding of this study is that the use of instructional video media can increase students' learning motivation in mathematics learning of students on the equivalent of currency values in class II SD Negeri 1 Bobotsari. The results of the study were indicated by an increase in the learning motivation of students in the first cycle $40 \%$, in the second cycle it increased to 92
\end{abstract}

Keywords: Motivation to learn, Mathematics, Video media

\begin{abstract}
Abstrak
Media merupakan salah satu komponen penting dalam meningkatkan motivasi belajar peserta didik. Tujuan penelitian ini adalah meningkatkan motivasi belajar peserta didik pada pembelajaran Matematika dengan menggunakan media video. Penelitian ini merupakan penelitian tindakan kelas (PTK) yang dilaksanakan dalam dua siklus, tiap siklus terdiri dari tahap perencanaan, pelaksanaan, observasi, dan refleksi. Subjek penelitian ini adalah peserta didik kelas II SD Negeri 1 Bobotsari yang berjumlah 25 peserta didik. Instrumen penelitian adalah lembar observasi, dan dokumentasi. Analisis data meliputi reduksi data, penyajian data, dan penarikan kesimpulan. Temuan penelitian ini adalah penggunaan media video pembelajaran dapat meningkatkan motivasi belajar peserta didik pada pembelajaran matematika peserta didik materi kesetaraan nilai mata uang di kelas II SD Negeri 1 Bobotsari. Hasil penelitian ditunjukkan dengan kenaikan motivasi belajar peserta didik pada siklus I $40 \%$, pada siklus II naik menjadi $92 \%$.
\end{abstract}

Kata kunci: Motivasi belajar, Matematika, Media video

Social, Humanities, and Education Studies (SHEs): Conference Series https://jurnal.uns.ac.id/shes 


\section{PENDAHULUAN}

Bagi peserta didik SD Negeri 1 Bobotsari persepsi negatif tentang matematika bahwa matematika merupakan mata pelajaran yang sulit sampai sekarang masih saja dominan dibandingkan persepsi positif. Hal ini sering terdengar dari percakapan peserta didik ketika membicarakan mata pelajaran matematika. Mereka mengatakan bahwa belajar matematika kurang menarik dan sulit.Terlebih lagi dimasa pandemi Covid 19 yang secara realita pembelajaran daring/jarak jauh diatur melalui Surat Edaran Kemdikbud No 4 Tahun 2020 mengenai Pelaksanaan Pendidikan Dalam Masa Darurat Coronavirus Disease (Covid-19).

Ada tiga poin kebijakan terkait pembelajaran daring, pertama, pembelajaran daring/jarak jauh untuk memberi pengalaman belajar yang bermakna, tanpa terbebani tuntutan menuntaskan seluruh capaian kurikulum untuk kenaikan kelas maupun kelulusan. Kedua, dapat difokuskan proses pembelajaran dilakukan secara daring. Hal ini menambah persepsi negatif tentang matematika menjadi meningkat. Persepsi negatif terhadap matematika berdampak pada rendahnya motivasi belajar yang berimplikasi pada rendahnya hasil belajar matematika.

Berdasarkan data awal disampaikan bahwa di kelas II SD Negeri 1 Bobotsari, menunjukkan bahwa saat pembelajaran daring pada muatan pelajaran matematika materi kesetaraan nilai mata uang, guru masih kurang dalam menggunakan media pembelajaran, sehingga motivasi belajar peserta didik dalam mengikuti kegiatan pembelajaran daring rendah dan menjadikan nilai yang diperoleh peserta didik masih belum maksimal. Oleh karena itu, agar motivasi belajar peserta didik tinggi, maka diperlukanlah media yang tepat untuk menyampaikan materi tersebut.Hal Ini sesuai dengan pendapat Asnawir dan 18 Basyiruddin ( 2002:11) bahwa media merupakan sesuatu yang bersifat menyalurkan pesan dan dapat merangsang pikiran, perasaan dan kemauan audiens (siswa) sehingga dapat mendorong terjadinya proses belajar pada dirinya.

Penerapan media pembelajaran yang inovatif untuk meningkatkan aktivitas peserta didik dan hasil yang memuaskan. Media yang tepat digunakan adalah video. Beberapa kelebihan Media Video apabila digunakan dalam proses pembelajaran, yaitu mampu menyampaikan konsep yang kompleks secara visual dan dinamik, mampu menarik perhatian peserta didik dan menyampaikan pesan dengan baik, mampu digunakan membantu menyediakan pembelajaran secara maya, dapat menciptakan pembelajaran yang lebih menyenangkan, menarik perhatian, meningkatkan motivasi serta merangsang pemikiran peserta didi yang lebih berkesan. Selain itu juga memudahkan dalam proses penerapan konsep ataupun demonstrasi. Daryanto (2010: 79). Penelitian dengan menggunakan media video juga sudah pernah dilakukan oleh Nissa Estika Zahrina yang berjudul "Penggunaan Media audio Visual untuk meningkatkan motivasi dan hasil belajar mata pelajaran IPS pada siswa kelas VI di MI Al falah pagu wates kabupaten Kediri.

Berdasar identifikasi penyebab masalah yang telah diuraikan pada latar belakang di atas, maka dapat dirumuskan masalah, yaitu Bagaimana penerapan penggunaan media video pembelajaran dapat meningkatkan motivasi belajar peserta didik pada muatan pelajaran Matematika kelas 2 SD Negeri 1 Bobotsari?".

Berdasarkan pada uraian di atas, penulis berupaya melakukan perbaikan pembelajaran melalui penelitian tindakan kelas dengan judul Penggunaan media video pembelajaran untuk meningkatkan motivasi belajar matematika kelas II SDN 1 Bobotsari. Tujuan penelitian ini adalah meningkatkan motivasi belajar peserta didik kelas II pada muatan pelajaran matematika materi kesetaraan nilai mata uang dengan menerapkan media video . 


\section{METODE}

Penelitian ini merupakan penelitian tindakan kelas (PTK) yang dilaksanakan dalam dua siklus. Setiap siklus dilaksanakan dalam 1 kali pertemuan yang terdiri dari tahap perencanaan, pelaksanaan, observasi, dan refleksi. Subjek penelitian ini adalah peserta didik kelas II SD Negeri 1 Bobotsari tahun pelajaran 2020/2021 yang berjumlah 25 peserta didik.

Data yang dianalisis berupa data kualitatif yaitu pengamatan proses penggunaan media video dalam. Teknik pengumpulan data menggunakan observasi. Uji validitas data menggunakan triangulasi teknik dan triangulasi sumber. Analisis data meliputi reduksi data, penyajian data, dan penarikan kesimpulan.

\section{HASIL DAN PEMBAHASAN}

Berdasarkan analisis hasil penelitian yang telah diuraikan maka pembahasan pada penelitian ini sebagai berikut.

\section{Hasil Peningkatan Motivasi Belajar dalam Proses Pembelajaran Matematika Menggunakan Media Video}

Hasil penelitian menunjukkan peningkatan aktivitas proses pembelajaran yang dilakukan guru dan peserta didik. Terlihat pada tabel berikut:

Tabel 1. Hasil Proses Pembelajaran matematika Menggunakan Media Video

\begin{tabular}{|l|l|l|l|}
\hline No & Jenis Aktifitas & Siklus I & Siklus II \\
\hline 1 & Motivasi Guru & 70 & 95 \\
\hline 2 & Motivasi Peserta Didik & 40 & 92 \\
\hline
\end{tabular}

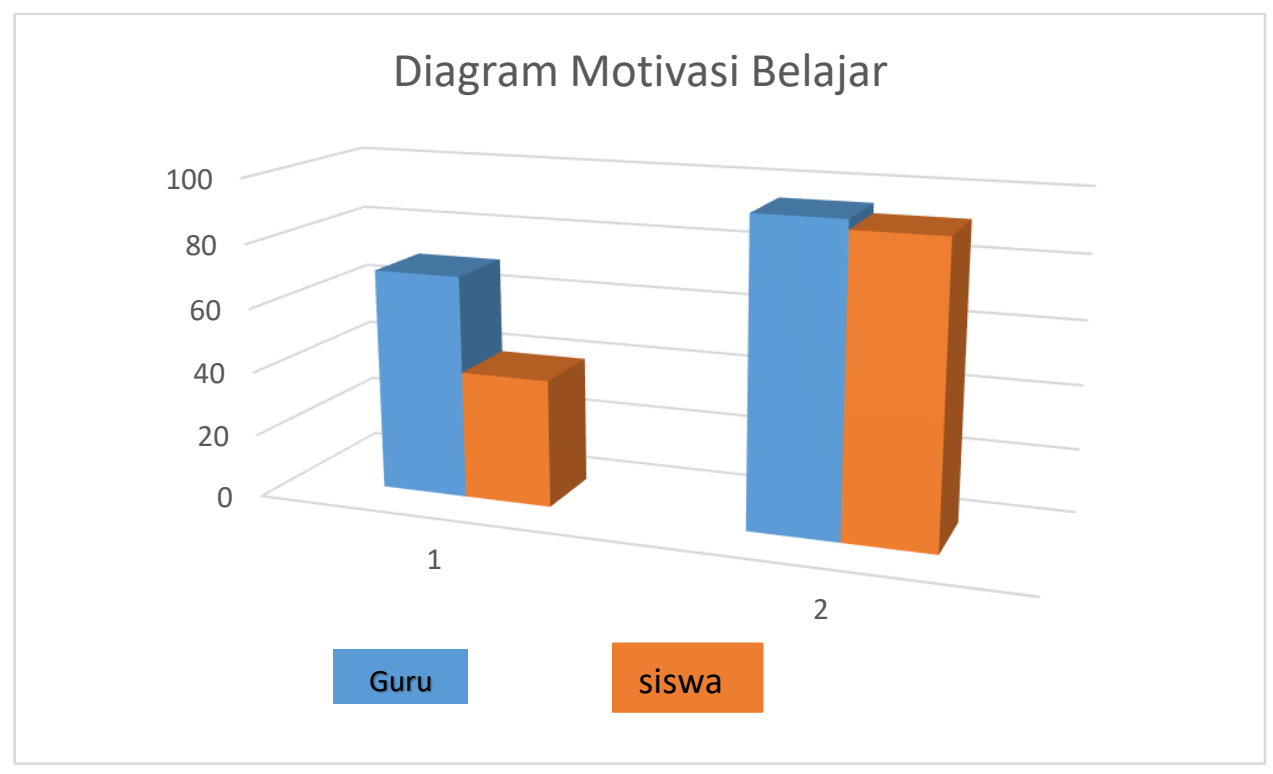

Diagram kenaikan motivasi belajar

Hasil peningkatan motivasi belajar peserta didik pada pembelajaran matematika dengan menggunakan Media Video 
Hasil Proses pembelajaran matematika pada Siklus I

Pertemuan pada siklus I dari aspek guru perolehan skor adalah $70 \%$.

Pertemuan pada siklus I dari aspek peserta didik perolehan skor adalah $40 \%$.

Data penelitian Siklus I tampak $70 \%$ untuk motivasi guru dan $40 \%$ untuk motivasi peserta didik menunjukan bahwa proses pembelajaran matematika menggunakan media video pembelajaran belum mencapai indikator keberhasilan yang ditetapkan oleh peneliti yaitu lebih besar atau sama dengan $80 \%(\geq 80 \%)$.

Dari catatan refleksi pembelajaran guru, pada siklus I masih ada kekurangan pada penggunaan media pembelajaran berbasis video, yaitu gambar tampilan video kurang jelas dan masih kurang menarik. Peserta didik menggunakan gawai yang berukuran kecil sehingga kualitas pembelajaran belum mengalami peningkatan yang berarti. Kemudian dari segi guru atau peneliti yaitu kurang maksimal dalam pengelolaan kelas maya. Peneliti masih kurang memberikan motivasi, penguatan, dan stimulus sehingga peserta didik kurang semangat dalam mengikuti kegiatan pembelajaran daring. Selain itu gangguan suara dari lingkungan luar juga mengganggu konsentrasi peserta didik yang sedang menyimak video pembelajaran kreatif dan interaktif.

Berdasarkan hasil pengamatan siklus I yang diperoleh, maka direncanakan untuk melakukan perbaikan pada pembelajaran berikutnya atau perbaikan selama proses pembelajaran pada siklus II. Pada siklus II nantinya guru harus memperhatikan kekurangan-kekurangan selama proses pembelajaran pada siklus I dan memperbaikinya pada siklus II.

Hasil Proses pembelajaran Matematika pada Siklus II

Pertemuan pada siklus II dari aspek guru perolehan skor adalah 95\%.

Pertemuan pada siklus II dari aspek peserta didik perolehan skor adalah 92\%.

Data penelitian Siklus II tampak 95\% untuk motivasi guru dan 92\% untuk motivasi peserta didik menunjukan bahwa proses pembelajaran matematika menggunakan media video pembelajaran sudah mencapai indikator keberhasilan yang ditetapkan oleh peneliti yaitu lebih besar atau sama dengan $80 \%(\geq 80 \%)$.

Pada pelaksanaan siklus II ini guru memberikan banyak kesempatan kepada peserta didik untuk melakukan semua langkah pembelajaran dengan menggunakan media video. Pada siklus ini peserta didik dibawa pada suasana kelas yang baru dan menyenangkan seperti yang dikemukakan oleh Bruner dalam Isti (1999:3.27). "Proses belajar mengajar akan berjalan dengan baik dan kreatif jika guru memberikan kesempatan kepada peserta didik untuk menentukan dan melakukan sesuatu".

Berdasarkan analisis penelitian siklus II, penerapan media video pembelajaran sudah sangat baik dalam pembelajaran matematika sehingga mampu meningkatkan kemampuan peserta didik dalam pemahaman konsep, (Agustiningsih: 2015)

Guru sebagai pengajar dan pendidik memiliki kewajiban untuk melaksanakan pembelajaran yang bermakna dan membekas pada diri peserta didik dengan memperhatikan beberapa aspek dalam pembelajaran antara lain kesesuaian dengan kebutuhan dan perkembangan peserta didik, serta memperhatikan keberhasilan peserta didik dalam memahami suatu materi pembelajaran disesuaikan dengan karakteristik dan tingkat kemampuan masing - masing. Guru berperan sebagai fasilitator dan motivator. Dalam membelajarkan peserta didik, guru harus memilih dan menggunakan berbagai strategi agar pembelajaran menjadi bermakna. (Rusman:2013) Oleh karena itu guru harus melakukan perbaikan dalam pelaksanaan pembelajaran serta perbaikan perangkat pembelajaran yang lebih inovatif. Dengan demikian kualitas 
pembelajaran akan meningkat diikuti dengan meningkatnya motivasi belajar peserta didik.

\section{SIMPULAN}

Berdasarkan hasil penelitian dan uraian pembahasan maka dapat diambil simpulan sebagai berikut.

Peneliti melakukan pelaksanaan pembelajaran matematika menggunakan media video pembelajaran pada materi kesetaraan nilai mata uang, dengan urutan sebagai berikut:1)Menggunakan platform geogle meet, 2)Menerapkan langkah-langkah penggunaan media video pembelajaran, 3) Menggunakan media video pembelajaran dengan animasi dan gambar yang menarik, 3) Menggunakan berbagai macam metode pembelajaran seperti ceramah dan tanya jawab, 4) Menciptakan suasana yang kondusif.

Penggunaan media video pembelajaran dalam pembelajaran matematika pada materi kesetaraan nilai mata uang di kelas II SD Negeri 1 Bobotsari, dapat meningkatkan motivasi belajar peserta didik dari segi proses pembelajaran. Hal ini dapat dilihat dari peningkatan persentase motivasi belajar peserta didik pada siklus I $40 \%$ naik pada siklus II menjadi $92 \%$.

\section{DAFTAR PUSTAKA}

Agustiningsih. (2015). Video Sebagai Alternatif Media Pembelajaran Dalam Rangka Mendukung Keberhasilan Penerapan Kurikulum 2013 Di SD, Jurnal Pedagogia, 4 (1) : 2089-3833

Daryanto. (2010). Media Pembelajaran. Yogyakarta: Gava media.

Mokhammad. (2018). Jenis-jenis media pembelajaran menurut para ahli dan contohnya https://www.haruspintar.com/jenis-jenis-media-pembelajaran/

Zaky. 2020. Pengertian Media Pembelajaran Menurut Para Ahli dan Secara Umum. https://www.zonareferensi.com/pengertian-media-pembelajaran/. 20.11. 